\title{
Beyond the basics: a detailed conceptual framework of integrated STEM
}

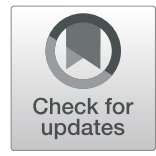

\author{
Gillian H. Roehrig ${ }^{1 *}$ (D, Emily A. Dare ${ }^{2}$, Joshua A. Ellis ${ }^{2}$ and Elizabeth Ring-Whalen ${ }^{3}$
}

\begin{abstract}
Given the large variation in conceptualizations and enactment of $\mathrm{K}^{-12}$ integrated STEM, this paper puts forth a detailed conceptual framework for $\mathrm{K}^{-12}$ integrated STEM education that can be used by researchers, educators, and curriculum developers as a common vision. Our framework builds upon the extant integrated STEM literature to describe seven central characteristics of integrated STEM: (a) centrality of engineering design, (b) driven by authentic problems, (c) context integration, (d) content integration, (e) STEM practices, (f) twenty-first century skills, and (g) informing students about STEM careers. Our integrated STEM framework is intended to provide more specific guidance to educators and support integrated STEM research, which has been impeded by the lack of a deep conceptualization of the characteristics of integrated STEM. The lack of a detailed integrated STEM framework thus far has prevented the field from systematically collecting data in classrooms to understand the nature and quality of integrated STEM instruction; this delays research related to the impact on student outcomes, including academic achievement and affect. With the framework presented here, we lay the groundwork for researchers to explore the impact of specific aspects of integrated STEM or the overall quality of integrated STEM instruction on student outcomes.
\end{abstract}

Keywords: Integrated STEM, Interdisciplinary teaching, Twenty-first century skills, Engineering design, Conceptual framework

\section{Beyond the basics: a detailed conceptual framework of integrated STEM}

Since the term "STEM" (Science-Technology-Engineering-Mathematics) was coined in 2001, there have been numerous efforts to improve $\mathrm{K}^{-12}$ STEM teaching and learning around the world (Freeman et al., 2014). With the release of STEM policy documents across the globe (e.g., Australian Curriculum, Assessment, and Reporting Authority, 2016; European Commission, 2015; Hong, 2017; National Research Council (NRC), 2012), the implementation of STEM in $\mathrm{K}^{-12}$ education has focused on interdisciplinary or integrated instruction, commonly referred to as "integrated STEM education", rather than separate disciplinary approaches to the teaching of science, technology, engineering, and mathematics. While

\footnotetext{
*Correspondence: roehr013@umn.edu

${ }^{1}$ Department of Curriculum and Instruction, University of Minnesota,

Minneapolis, USA

Full list of author information is available at the end of the article
}

integrated STEM education is well established through national and international policy documents, disagreement on models and effective approaches for integrated STEM instruction continues to be pervasive and problematic (Moore et al., 2020). Sgro et al. (2020) argue that, in essence, integrated STEM is "whatever someone decides it means" and that the large variation across integrated STEM curricula suggests a need for "greater clarity about not only what constitutes STEM education, but how educators as a whole conceptualize STEM and the process of integration" (p. 185). In response, this paper puts forth a detailed conceptual framework for $\mathrm{K}^{-12}$ integrated STEM education that can be used by researchers, educators, and curriculum developers as a common vision.

Various broad definitions of integrated STEM education exist in the literature and policy documents. For example, Moore, Stohlmann, and colleagues (2014) defined integrated STEM education as "an effort to combine 
some or all of the four disciplines of science, technology, engineering, and mathematics into one class, unit, or lesson that is based on connections between the subjects and real-world problems" (p. 38). Similarly, Kelley and Knowles (2016) defined integrated STEM as "the approach to teaching the STEM content of two or more STEM domains, bound by STEM practices within an authentic context for the purpose of connecting these subjects to enhance student learning" (p. 3). Common across almost all definitions is the use of real-world contexts to both contextualize learning and motivate student engagement (e.g., Kelley \& Knowles, 2016; Kloser et al., 2018; National Academy of Engineering (NAE) and NRC, 2014). While some researchers argue for integration across all four of the STEM disciplines (e.g., Burrows et al., 2018; Chandan et al., 2019), others call for the integration of at least two of the STEM disciplines (e.g., Moore et al., 2020). Given the prominence of engineering within STEM policy documents (e.g., NRC, 2012; NGSS Lead States, 2013), many approaches to integrated STEM specifically include an engineering context or engineering design problem as the context for learning (e.g., Berland \& Steingut, 2016; Mehalik et al., 2008; Moore, Stohlmann, et al., 2014). Indeed, Nathan et al. (2013) argue, the ideals of STEM integration are not likely to be fulfilled by the integration of any pair of STEM fields ... the pairing of technology with engineering (the design sciences) is insufficient to satisfy STEM integration, and also excludes pairing science and math (the natural sciences). Rather, it calls for STEM integration that spans the design and natural sciences. (p. 82).

In addition to the centrality of engineering and connection to real-world problems, other aspects of integrated STEM on which there is consensus in the literature include: (a) the use of student-centered pedagogies (e.g., Asunda \& Mativo, 2017; Johnson et al., 2016; Thibaut et al., 2018), (b) supporting the development of twenty-first century skills such as creativity, collaboration, communication, and critical thinking (e.g., Sias et al., 2017; Wang \& Knoblach, 2018), and (c) connections between STEM disciplines should be made explicit to students (e.g., English, 2016; Kelley \& Knowles, 2016; NAE and NRC, 2014). While there is consensus on these aspects as being central to broad definitions of STEM, the literature does not provide detail on how these aspects should be operationalized for quality implementation of integrated STEM education in $\mathrm{K}^{-12}$ classrooms.

While integrated STEM education is not restricted to implementation in science classrooms, in the United States there exists a policy mandate to $\mathrm{K}^{-12}$ science teachers through the Framework for $\mathrm{K}^{-12}$ Science Education (NRC, 2012) and the Next Generation Science
Standards (NGSS Lead States, 2013) and consequently the preponderance of integrated STEM research occurs within the context of science education (Takeuchi et al, 2020). Thus, in this paper we specifically focus on STEM integration within $\mathrm{K}^{-12}$ science classrooms. It is also important to state that integrated STEM is not promoted to the exclusion of other important learning goals within a $\mathrm{K}^{-12}$ science classroom. Plainly stated, not all science content can and should be taught using an integrated STEM approach; attention should also be paid to the nature of science and engaging students in learning science concepts through inquiry-based learning.

While the field has moved towards increased agreement on definitions and broad characteristics of integrated STEM education, there remains a lack of specification in how these characteristics should be operationalized within curricula and classrooms. Educators and curriculum developers need specifics if the implementation of integrated STEM education is to meet the policy goals of using interdisciplinary and integrated approaches to teaching STEM content to increase students' interest and readiness for STEM careers (e.g., National Academy of Science, National Academy of Engineering, and Institute of Medicine, 2007; President's Council of Advisors on Science and Technology [PCAST], 2011). Without clear guidelines, implementation of integrated STEM education comprises a broad range of approaches (Moore et al., 2020), many of which, as discussed below, are problematic (e.g., Gunckel \& Tolbert, 2018; McComas \& Burgin, 2020). There is a clear need for research to provide critical evidence of the impact of integrated STEM education on student learning and affect toward STEM, as many arguments for integrated STEM are argued from policy and theoretical positions (e.g., NAE and NRC, 2014). The development of valid assessments and protocols to research integrated STEM teaching and learning requires that characteristics of integrated STEM education are developed in explicit detail. Thus, this paper develops a detailed framework for integrated STEM education that expands on previously established components of quality integrated STEM as broad statements to detailed constructs that describe fully what quality integrated STEM implementation should look like in the classroom. First, we examine the policy environment in which integrated STEM education is being promoted. Second, we provide an extensive literature review which expands on the consensus aspects of integrated STEM education described above to provide a more nuanced and detailed discussion of key characteristics of integrated STEM.

\section{STEM policy}

It is important to understand the policy context in which integrated STEM education is being promoted, as the 
myriad approaches are in response to policy directives, originating within the US, that call for addressing pressing issues such as STEM workforce needs (Takeuchi et al., 2020). Indeed, dominating policy arguments is the suggestion that continued national prosperity is dependent on meeting STEM workforce needs to address critical challenges such as energy, health, the environment, national security, and global development (e.g., National Academy of Science, National Academy of Engineering, and Institute of Medicine, 2007; PCAST, 2011). The number of STEM jobs is growing faster than non-STEM jobs (U.S. Bureau of Labor Statistics, 2020), which may result in a shortage of up to 3.5 million STEM workers in the United States by 2025 (National Association of Manufacturing and Deloitte Report, 2018). STEM workforce arguments are used in countries throughout the world to establish new STEM education policies and initiatives (Freeman et al., 2014). However, policy documents do not unpack specifics about STEM workforce needs beyond shortages of STEM workers. For integrated STEM education to address policy calls related to the STEM workforce, it is necessary to better understand the knowledge and skills that students need to be successful as STEM professionals.

More specific to the needs of the STEM workforce are concerns about a "creativity crisis" in the United States and around the world (Bronson \& Merryman, 2011; Kim, 2011; Lin, 2011). STEM employers are looking for a workforce with not only strong STEM content knowledge and skills, but also an ability to compete in the global economy in a workforce with strong twenty-first century skills (e.g., critical thinking, communication, collaboration, and creativity) (Bronson \& Merryman, 2011; Charyton, 2015). According to a World Economic Forum survey, approximately $65 \%$ of today's Kindergarteners will end up working in jobs that do not currently exist given the rapid growth of automation and artificial intelligence in the workplace (World Economic Forum, 2016). Thus, it is no longer enough to expect our students to simply learn isolated facts and content. Rather than positioning students as consumers of information, students should be involved in knowledge construction. The deep understanding of content developed through knowledge construction forms the basis for students to apply twenty-first century skills to create, analyze, evaluate, innovate, and address real-world problems (Stehle \& Peters-Burton, 2019).

Less visible in the current STEM policy rhetoric are arguments that integrated STEM education should promote increased STEM literacy and awareness, as well as addressing issues in developing countries related to equitable education and poverty reduction (Freeman et al., 2014; National Academy of Sciences [NAS], 2014). Indeed, teaching STEM solely from a workforce rationale is viewed by some science educators as problematic (e.g., Hoeg \& Bencze, 2017; Zeidler, 2016; Zeidler et al., 2016). For example, Gunckel and Tolbert (2018) call out the technocratic, utilitarian, and neoliberal underpinnings of engineering design as portrayed in the Framework (NRC, 2012). These critiques are carefully considered and integrated in our development of an understanding of integrated STEM education to guide both educators and researchers seeking to better understand integrated STEM and ensure a positive learning experience for all students.

\section{Integrated STEM framework}

Throughout this literature review, we propose a framework for $\mathrm{K}^{-12}$ integrated STEM education that provides essential details for consistent implementation and evaluation of integrated STEM teaching. Without common understandings of integrated STEM education, it is difficult at best to draw conclusions across studies about teacher practices related to integrated STEM instruction and student outcomes. This common understanding needs to move past definitions and lists of consensus features of integrated STEM that can be interpreted in myriad ways by educators. Our framework includes seven key characteristics of integrated STEM: (a) focus on real-world problems, (b) centrality of engineering, (c) context integration, (d) content integration, (e) STEM practices, (f) twenty-first century skills, and (g) informing students about STEM careers. Table 1 provides a summary of these characteristics, and a detailed literature review for each characteristic follows this overview of the framework. These key characteristics are aligned with and expand upon three of the four consensus features of integrated STEM identified in the preceding sections: (a) integrated STEM is contextualized by a real-world problem, (b) integrated STEM supports the development of twenty-first century skills, and (c) connections between STEM disciplines should be made explicit to students. We note agreement within our framework that integrated STEM requires the use of student-centered pedagogies; however, we focus on student engagement in STEM practices rather than broad notions of student-centered pedagogies. Our framework extends conceptualizations of integrated STEM to explicitly address the nature of integration, the role of engineering, and STEM career awareness. Finally, our framework directly attends to issues of diversity and equity as opposed to the techno-centric focus of prevalent conceptualizations of integrated STEM. It is important to note that none of the characteristics in Table 1 operate in isolation from each other (see Fig. 1). The following section grounds each characteristic in the 
Table 1 Seven Key Characteristics of Integrated STEM

\begin{tabular}{|c|c|}
\hline Characteristic & Description \\
\hline $\begin{array}{l}\text { 1. Focused on } \\
\text { real-world } \\
\text { problems }\end{array}$ & $\begin{array}{l}\text { Real-world problems: } \\
\text { - contextualize learning (Kelley \& Knowles, 2016; Kloser et al., } \\
\text { 2018) } \\
\text { - } \text { should foster multiple solutions (Lachapelle \& Cunningham, } \\
\text { 2014) } \\
\text { • engage learners in applying and expanding their STEM } \\
\text { knowledge (Monson \& Besser, 2015) } \\
\text { - should be motivating and relevant to students (Diekman et al., } \\
\text { 2010; Leammukda \& Roehrig, 2020) } \\
\text { - should, when possible, position students as agents of change } \\
\text { (Billington et al., 2013; Gunckel \& Tolbert, 2018). }\end{array}$ \\
\hline
\end{tabular}

2. Engagement in - Students are expected to have opportunities in engineering

design $\quad$ Students should engage in the full engineering design process, with opportunities to learn from failure and iteratively improve their design solutions (Moore, Glancy, et al., 2014; NRC, 2012; Stretch \& Roehrig, 2021)

- Teachers need to empathize dimensions of ethics, care, and empathy to promote attention to socio-political aspects of engineering design (Gunckel \& Tolbert, 2018; Jackson et al., 2021)

3. Context - Integrated STEM contexts provide opportunities to learn and integration apply STEM content (Arık \& Topçu, 2020; Reynante et al., 2020)

- Evidence-based reasoning provides explicit scaffolding for application of STEM content to the real-world problem (Mathis et al., 2016; Mathis et al., 2018; Siverling et al., 2017)

- Criteria and constraints should be explicitly addressed during the design process (Watkins et al., 2014)

- The broader socio-political context of the engineering design problem should be explicitly addressed (Gunckel \& Tolbert, 2018)

4. Content integration

- Students should have opportunities to learn and apply STEM content to the development of design solutions (Tank et al., 2019; Tran \& Nathan, 2010)

- Connections amongst the STEM disciplines need to be explicit (English, 2016; Moore, Stohlmann, et al., 2014; Tran \& Nathan, 2010)

- Content integration can be achieved through multidisciplinary, interdisciplinary, or transdisciplinary approaches (Bybee, 2013; Moore \& Smith, 2014; Vasquez et al., 2013)

- Mathematics and technology should not be limited to tools in service to science and engineering (Authors, 2019, 2021a;

Baldinger et al., in press; Walker, 2017)

- Non-STEM disciplines should be explicitly integrated as relevant to developing solutions and understanding the broader socio-political context of the problem (Gunckel \& Tolbert, 2018)

5. Engagement in - Students should have opportunities to engage in STEM authentic STEM practices (e.g., Kelley \& Knowles, 2016; Reynante et al., 2020) practices

- Students' use of STEM practices should not be teacherproscribed (Authors, 2013; Asunda, 2014; Guzey, Moore, \& Harwell, 2016; Riskowski et al.,2009)

- Students should have epistemic agency, drawing on cultural and personal knowledge and practices in addition to STEM practices (Miller et al., 2018; Schwarz et al., 2017)

- Critical to STEM are data practices (Duschl et al., 2007), including evidence-based reasoning (Mathis et al., 2016; Mathis et al., 2018; Siverling et al., 2017)

6. twenty-first cen- • Integrated STEM instruction should support the development tury skills

\section{In the classroom}

The selection of a real-world problem is a complex process as there are many factors that impact both cognitive and affective student outcomes. Gender and ethnicity should be explicit considerations in choosing a real-world problem to promote the student engagement and development of strong STEM identities for all students.

Teachers need to ensure that students have opportunities to evaluate their designs and use collected data to redesign. Design decisions should include analysis of social and political considerations in addition to technical factors such as cost, materials, and functionality.

Teachers need to take care that an engineering design challenge does not become an exercise in tinkering. Makerspaces and many engineering curricula are not reflective of quality integrated STEM as the connections between STEM content and the context are implicit. Teachers need to explicitly make connections by engaging students in reflection and evidence-based reasoning. Real-world contexts encompass social and political issues that need to be explicitly addressed in addition to the technical focus of consideration of STEM content, criteria, and constraints.

Most critical to integration is making connections between the disciplines and between the context and disciplines explicit to students. Teachers need to model the connections for

students, use interdisciplinary models and representations, and use purposeful facilitation and questioning to promote students' understanding of these connections. The integration of non-STEM disciplines broadens the students' experience with engineering beyond a technocratic focus, pedagogical approaches such as socio-scientific issues can elevate the sociopolitical aspects of a real-world problem that need to be considered in developing design solutions.

Integrated STEM education requires that students are afforded the opportunity to determine their own solution paths. Teacher proscribed directions will result in a single design solution, and integrated STEM education calls for the possibility of multiple possible solutions to a problem. The open-ended nature these integrated tasks requires careful facilitation from teachers, helping students to understand the STEM practices in which they are engaging and reflecting on their process. Students should engage in data practices and evidence-based reasoning to justify their design decisions.

III-defined problems lend themselves to students' development of twenty-first Century Skills as they engage in iterative design thinking. Teachers need to structure small group activities to support collaboration, critical thinking, creativity, and higher order cognitive tasks, such as analyzing and evaluating. Teachers need to carefully facilitate small group work to support equal participation of all students. Students require explicit 
Table 1 Seven Key Characteristics of Integrated STEM (Continued)

\begin{tabular}{|c|c|c|}
\hline Characteristic & Description & In the classroom \\
\hline & $\begin{array}{l}\text { - Engagements in small group STEM activities differs for female } \\
\text { students and students of color compared to their white male } \\
\text { peers (Authors, 2024, 2020b) }\end{array}$ & instruction on working in small groups. \\
\hline 7. STEM careers & $\begin{array}{l}\text { - Exposure to details about STEM careers (Jahn \& Myers, 2014; } \\
\text { Luo et al., 2021) } \\
\text { - Opportunities to engage in authentic STEM practices (Kitchen } \\
\text { et al., 2018; Ryu et al., 2018) } \\
\text { - Attend to identity development by connecting to personal } \\
\text { knowledge and experience (Carlone et al., 2014) }\end{array}$ & $\begin{array}{l}\text { Teachers need to describe specific STEM careers relevant to the } \\
\text { topic, including exposure to role models. Students would have } \\
\text { opportunities to learn about the work of STEM professionals by } \\
\text { using STEM practices and applying STEM content and personal } \\
\text { experience to proposing solutions to real-world problems. }\end{array}$ \\
\hline
\end{tabular}

literature and illustrates the connections amongst the characteristics.

\section{Focus on real-world problems}

If learning is not centered on developing solutions to a real-world problem (Characteristic 1), a lesson cannot be considered to be representative of integrated STEM education. Indeed, as noted earlier, the most common feature included in definitions of integrated STEM in the literature is that STEM integration should be centered around a real-world problem or context (e.g., Kelley \& Knowles, 2016; Kloser et al., 2018; Moore et al., 2020). Indeed, many students find it difficult to relate to STEM content presented using traditional, disciplinary approaches (Kelley \& Knowles, 2016). Proponents of integrated STEM education argue that using real-world or authentic problems as a context for learning provides motivation and purpose for learning STEM content (e.g., Kelley \& Knowles, 2016; Monson \& Besser, 2015). Research shows that engaging students in learning through authentic engineering design problems improves student interest in science and engineering (Guzey, Moore, \& Morse, 2016; Lachapelle \& Cunningham, 2014; McClure et al., 2021). However, the selection of a real-world problem requires careful consideration as the ability to engage students with all characteristics of integrated STEM education hinges on the nature of the real-world problem (Fig. 1).
Our framework expands consideration of the importance of the nature of these real-world problems as care needs to be taken that these authentic problems generate interest and motivation in learning for all students (Carter et al., 2015; Monson \& Besser, 2015). Given the lack of diversity within many of the STEM fields (Vakil \& Ayers, 2019), there is a need to increase STEM interest for students that are historically under-represented in STEM. It is important to engage students in realworld problems that are personally motivating and connect STEM content to students' lived experiences. This has been shown to make learning more meaningful and relevant, which enhances student engagement in science (Djonko-Moore et al., 2018) and positions students as epistemic agents in their learning (Miller et al., 2018). Often, integrated STEM classroom activities tend to focus on the male-oriented, technical aspects of engineering related to the design of "things", such as designing cars and rockets (Gunckel \& Tolbert, 2018). However, research shows that girls and students of color are more motivated by projects with a communal goal orientation, focused on societal issues such as health, the environment, and social justice as opposed to these types of gendered engineering projects (Billington et al., 2013; Diekman et al., 2010; Leammukda \& Roehrig, 2020). The emphasis on "things" and technical criteria is oppositional to a communal goal orientation which negatively impacts interest in STEM careers (Diekman et al.,

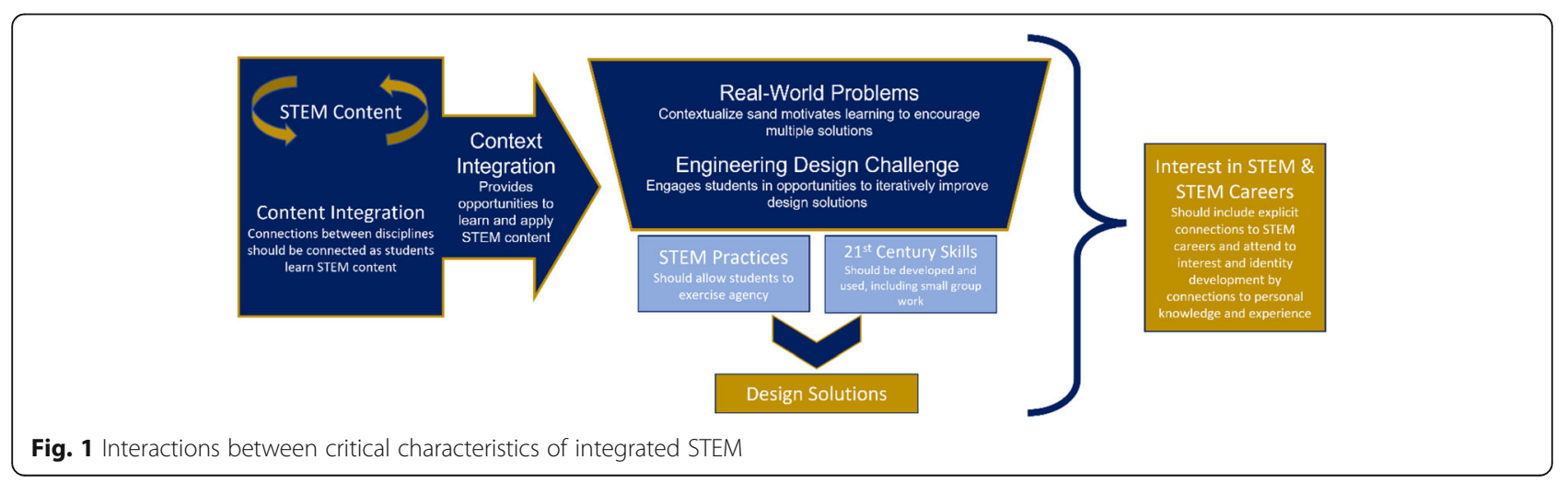


2010). This line of research parallels the arguments of Gunckel and Tolbert (2018), who argue for considerations of the dimensions of care and empathy in integrated STEM. While the literature has demonstrated a clear consensus that integrated STEM education should include an authentic problem to contextualize learning (e.g., Kelley \& Knowles, 2016; Moore, Stohlmann, et al., 2014), there are important considerations about the nature of such problems if content learning and student motivation are to be promoted as argued in policy documents (e.g., Australian Curriculum, Assessment, and Reporting Authority, 2016; European Commission, 2015; NRC, 2012). Drawing on personal and community interests and lived experiences of students will be more motivating for students, and with purposeful consideration of students' interests there is the potential to diversify STEM fields.

\section{Centrality of engineering}

Given the prominence of engineering within STEM policy documents (e.g., NRC, 2012), real-world problems are represented as an engineering design challenge (Characteristic 2) (Moore et al., 2020). Engineering is considered central in most definitions of integrated STEM (e.g., Berland \& Steingut, 2016; Mehalik et al., 2008; Moore, Stohlmann, et al., 2014; Nathan et al., 2013); even within research that calls for the integration of only two disciplines to be considered integrated STEM, the most common combination is science and engineering (Moore et al., 2020). Thus, our framework links real-world problems to engineering design challenges (Characteristics 1 and 2 in Fig. 1) to promote the practices called for within current reform documents (e.g., NRC 2012).

Developing solutions to an overarching real-world problem relies on using and developing understanding of content from multiple disciplines (e.g., Cavlazoglu \& Stuessy, 2017; Thibaut et al., 2018; Walker et al., 2018). Specifically, within integrated STEM education, students are expected to engage in engineering practices to develop possible design solutions to real-world problems (Berland \& Steingut, 2016; NAE and NRC, 2014; NRC, 2012). Engineering practices are loosely defined within the NGSS through the eight science and engineering practices; however, successful integration of engineering practices into science classrooms requires a more robust articulation of engineering practices (Cunningham \& Carlsen, 2014; Moore, Glancy, et al., 2014). In our work, we draw heavily on the Framework for Quality $\mathrm{K}^{12} \mathrm{En}$ gineering Education (Moore, Glancy, et al., 2014), which proposes three domains consisting of 12 key indicators of quality K-12 engineering (see Table 2).

Engineering is a systematic and iterative approach to designing solutions (products, processes, and systems) based on the needs of a client (NRC, 2012). As such, design is widely considered to be the central activity of engineering (Dym, 1999). Engineering design is an iterative process of "testing the most promising solutions and modifying what is proposed on the basis of the test results leads to greater refinement and ultimately to an optimal solution" (NRC, 2012, p. 210). In other words, response to failure is central to the engineering design process; failure is expected if innovation is to occur as it can lead to stronger, more innovative designs (Henry et al., 2021; Simpson et al., 2018). Thus, it is critical that K-12 students have opportunities within integrated STEM curriculum to fully engage in the iterative engineering design process and engage in at least one cycle of evaluating and redesigning a proposed solution or set of solutions (Moore, Stohlmann, et al., 2014). Learning from failure needs to be explicitly scaffolded for students, purposefully engaging them in a reflective decision-making process (Wendell et al., 2017).

Unfortunately, in K-12 classrooms engineering design is usually depicted solely as a technical problem (Gunckel \& Tolbert, 2018). Thus, our framework expands on the Framework for Quality K-12 Engineering Education (Moore, Glancy, et al., 2014) to extend its focus on the technical aspects of engineering design to explicitly consider diversity and equity within STEM. Parallel to the work of professional engineers, students are expected to understand and address the criteria and constraints of a problem in developing possible design solutions (Watkins et al., 2014). Yet, these constraints are usually limited to realistic, but surface-level, issues such as time, access to materials, and budget, often ignoring the social, political, and ethical issues that are inherent in most real-world problems (Gunckel \& Tolbert, 2018; Roehrig et al., 2020). Indeed, some researchers argue the NGSS (NGSS Lead States, 2013) and the Framework (NRC, 2012) marginalize the moral and ethical considerations within engineering design (e.g., Kahn, 2015). Gunckel and Tolbert (2018) caution that, while engineering education has elevated a focus on ethics, the focus of this approach still draws on technocratic and utilitarian principles. An approach grounded in care and empathy is necessary to reframe engineering education to engage students in considering the societal implications of their design solutions (Gunckel \& Tolbert, 2018; Jackson et al., 2021). Similarly, researchers have promoted the inclusion of socio-scientific issues (SSI) into integrated STEM instruction (Kahn, 2015; Owens \& Sadler, 2020; Roehrig et al., 2020). In addition to promoting scientific solutions to a real-world problem, SSI explicitly address moral and ethical considerations (Kahn, 2015; Zeidler, 2016). This approach to integrated STEM education not only elevates the purpose to include STEM literacy for all citizens regardless of their 
Table 2 Domains and key indicators for quality K-12 engineering

\begin{tabular}{|c|c|c|}
\hline Domain & Indicators & Description \\
\hline \multirow[t]{3}{*}{$\begin{array}{l}\text { Central to engineering and } \\
\text { engineering education }\end{array}$} & $\begin{array}{l}\text { Process of Design (POD) } \\
\text { - Problem and background } \\
\text { - Plan and implement } \\
\text { - Test and evaluate }\end{array}$ & $\begin{array}{l}\text { Common elements of an iterative engineering design process are problem } \\
\text { identification and scoping, ideation, design, testing, and redesign (Dym, 1999). }\end{array}$ \\
\hline & $\begin{array}{l}\text { Apply science, engineering, and } \\
\text { mathematics content (SEM) }\end{array}$ & $\begin{array}{l}\text { The practice of engineering requires the application of science, mathematics, and } \\
\text { engineering knowledge. K- } 12 \text { STEM education should emphasize this interdisciplin- } \\
\text { ary nature by providing students with opportunities to apply developmentally ap- } \\
\text { propriate mathematics or science in the context of solving engineering problems } \\
\text { (Arı \& Topçu, 2020). }\end{array}$ \\
\hline & Engineering thinking (EThink) & $\begin{array}{l}\text { Engineers engage in reflective decision-making and argumentation (Couso \& } \\
\text { Simarro, 2020; Wendell et al., 2017). }\end{array}$ \\
\hline \multirow{2}{*}{$\begin{array}{l}\text { Development of an } \\
\text { understanding of } \\
\text { engineering }\end{array}$} & $\begin{array}{l}\text { Conceptions of engineering and } \\
\text { engineers (CEE) }\end{array}$ & $\begin{array}{l}\text { Students should learn about the profession of engineering, types of engineering, } \\
\text { and pathways to becoming an engineer. }\end{array}$ \\
\hline & Engineering Tools (ETools) & Engineers use specific tools, processes, and techniques in their work. \\
\hline \multirow{4}{*}{$\begin{array}{l}\text { Professional skills used by } \\
\text { engineers }\end{array}$} & Issues, solutions, and impacts (ISI) & Awareness of current real-world problems, both locally and globally. \\
\hline & Ethics & $\begin{array}{l}\text { Engineering ethics addresses the moral issues and decisions that confront } \\
\text { engineers (Martin \& Schinzinger, 1989). }\end{array}$ \\
\hline & Teamwork (Team) & \multirow{2}{*}{$\begin{array}{l}\text { Successful engineers need more than strong technical capabilities; they also need } \\
\text { skills in communication and the ability to work effectively within a team (Shuman } \\
\text { et al., 2005). }\end{array}$} \\
\hline & $\begin{array}{l}\text { Communication related to } \\
\text { engineering (Comm-Engr) }\end{array}$ & \\
\hline
\end{tabular}

future participation in a STEM career, but also reimagines the necessary skills needed in the STEM workforce to improve and diversify thinking and approaches to engineering design.

\section{Context integration}

The real-world problem and/or engineering design challenge used to motivate student learning should be complex enough to foster multiple solutions (Lachapelle \& Cunningham, 2014) and engage learners in applying and expanding their knowledge of the STEM disciplines (Berland \& Steingut, 2016; Monson \& Besser, 2015). There needs to be clear alignment between the engineering design challenge or real-world problem and specific content learning objectives (see Fig. 1), with the challenge or problem framed such that students need to draw upon STEM content knowledge to generate possible designs and make evidence-based decisions. This is represented in Fig. 1 as context integration (Characteristic 3).

Without clear and explicit integration between the problem context and content learning goals, students will resort to tinkering (a form of trial and error), negating the achievement of content learning objectives (McComas \& Burgin, 2020; Moore, Glancy, et al., 2014; Roehrig et al., 2021). This relates to a significant problem pointed out by Takeuchi et al. (2020) in that there is a lack of a clear focus on specific STEM concepts. In their systematic review of the literature, Takeuchi et al. (2020) reported that almost $40 \%$ of the 154 integrated STEM articles they reviewed focused on students' career aspirations and choices rather than learning of specific
STEM concepts. The real-world problem and engineering design challenge must provide a context for learning target STEM content, as well as being motivating and engaging for students to help promote positive STEM identities (e.g., Tai et al., 2006).

Unfortunately, even with a real-world context, design tasks can degenerate into simply making crafts or tinkering solely through trial and error, neither of which require knowledge of STEM content or practices to develop solutions. While engineers develop both products and processes as solutions to real-world problems, K-12 engineering and integrated STEM educators tend to gravitate toward the building of physical products. For example, engineering courses, makerspaces, and digital fabrication labs have proliferated in K-12 schools over the past decade (Adams Becker et al., 2016). The focus of makerspaces and fabrication labs is the development of a product, often through "tinkering with materials with an endpoint in mind" (Sheffield et al., 2017, p.149). In effect, these spaces are the modernized versions of vocational education or shop class (Blackley et al., 2017; McComas \& Burgin, 2020). Studies demonstrate limited content learning in science and mathematics for students participating in hands-on, project-based engineering courses because of the lack of clear and explicit connections to science and mathematics content (Tank et al., 2019). Makerspaces, fabrication labs, and engineering programs are not commensurate with characteristics of integrated STEM education unless teachers make explicit connections to mathematics and science content (Sheffield et al., 2015). As such, integrated STEM education requires an authentic problem or 
engineering design challenge that engages students in explicitly learning and applying science and mathematics concepts.

The practice of engineering requires the use and application of science, mathematics, and engineering knowledge. K-12 STEM education should emphasize this interdisciplinary nature by providing students with opportunities to apply developmentally appropriate mathematics or science content within the context of solving engineering problems (Arı \& Topçu, 2020; NRC, 2012; Reynante et al., 2020). Indeed, engineering as a discipline involves an "understanding of the science undergirding physical relationships and the mathematical foundations of models that guide engineering design, as opposed to tinkering or making random modifications without basing those changes upon mathematical and/or scientific analyses" (Householder \& Hailey, 2012, p.12). Design iterations throughout the engineering design process are based on evidence, scientific and mathematical knowledge, and analyses of the data generated through the testing of prototype designs (Mathis et al., 2016; Mathis et al., 2018).

Our argument is that integrated STEM education at its core is driven by real-world problems and the development of possible solutions to those problems using knowledge and practices from any relevant discipline. If students are to consider and understand the full sociohistorical-political context of the problems in developing and evaluating design solutions to real-world problems (e.g., Gunckel \& Tolbert, 2018), then knowledge and practices from the social sciences are necessary in addition to the technical knowledge of the STEM disciplines. In addition, critical to addressing issues of equity and diversity in STEM, is promoting students' lived experiences and cultural knowledge, as well as disciplinary knowledge, as relevant to proposing solutions to realworld problems and engineering design challenges. Unfortunately, the cultural knowledge of students who are marginalized and under-represented in STEM are often perceived as deficit and not as legitimate ways of engaging in STEM (Tan \& Calabrese Barton, 2018). Limited attention has been paid within the integrated STEM education literature to elevating the application of cultural and indigenous knowledge in engineering design; however, promoting STEM interest and learning for all students needs to attend to approaches such as cultural maker education (Tan \& Calabrese Barton, 2018) and ethno-engineering (Friesen \& Herrmann, 2018; Kilada et al., 2021).

\section{Content integration}

In addition to explicit connections between the realworld problem/engineering design challenge and the targeted science and/or mathematics content
(Characteristic 3 - contextual integration), it is important that connections between the disciplines (Characteristic 4 - content integration) are also made explicit to students (English, 2016; Kelley \& Knowles, 2016; NAE and NRC, 2014). Although teachers may understand the connections across the range of content representations and activities within an integrated STEM lesson, students often struggle to make these connections on their own (Dare et al., 2018; Tran \& Nathan, 2010). Since students seldom make these connections spontaneously (Tran \& Nathan, 2010), teachers must either help students recognize and identify these connections or explicitly make these connections clear for students. In a study of a high school engineering classroom, Nathan et al. (2013) discuss productive pedagogical moves to help make these interdisciplinary connections explicit to students. Their suggestions include asking questions, facilitating problem solving, creating models and representations, and explicitly foregrounding disciplinary knowledge to help students to identify the presence of specific content.

Content integration can be achieved through multidisciplinary, interdisciplinary, or transdisciplinary approaches (Bybee, 2013; Moore \& Smith, 2014; Vasquez et al., 2013). Some researchers argue that one approach is not superior to another (Rennie et al., 2012), whereas others define a continuum of increasing integration from disciplinary to transdisciplinary (e.g., Vasquez et al., 2013; Wang \& Knoblach, 2018). Proponents of an interdisciplinary approach argue that this approach is superior because a theme or real-world problem anchors the learning (e.g., Vasquez et al., 2013) in contrast to multidisciplinary approaches that "begin and end with the subject-based content and skills [with] students expected to connect the content and skills in different subjects that had been taught in different classrooms" (Wang et al., 2011, p.2).

While many researchers define multidisciplinary integration as occurring across multiple classrooms (e.g., Vasquez et al., 2013), the calls to integrate engineering and mathematical thinking in science classrooms (e.g., NRC, 2012) require integration across the disciplines within a science lesson or unit of instruction (Capobianco \& Rupp, 2014; Moore, Stohlmann, et al., 2014). In a multidisciplinary approach, each STEM discipline would be identifiable within the curriculum and instruction, whereas in an interdisciplinary approach, each discipline would be difficult to distinguish from one another (Lederman \& Niess, 1997). Given the argument that integrated STEM education can improve students' learning of science and mathematics concepts (e.g., Berland \& Steingut, 2016; Fan \& Yu, 2017; Guzey et al., 2017) and the difficulty faced by students in recognizing the way in which 
different content areas support and complement each other (English, 2016; NAE and NRC, 2014), the connections between content areas need to be made explicit for students (English, 2016; Kelley \& Knowles, 2016). As stated in the NAE and NRC (2014) report:

Connecting ideas across disciplines is challenging when students have little or no understanding of the relevant ideas in the individual disciplines. Also, students do not always or naturally use their disciplinary knowledge in integrated contexts. Students will thus need support to elicit the relevant scientific or mathematical ideas in an engineering or technological design context, to connect those ideas productively, and to reorganize their own ideas in ways that come to reflect normative, scientific ideas and practices. (p. 5)

While not discounting transdisciplinary and interdisciplinary approaches to integrated STEM education, multidisciplinary approaches yield the best approach for students to learn and apply disciplinary content and develop an understanding of the ways in which disciplinary content is connected.

Given the positioning of engineering within national and state science standards, mathematics and technology have received little attention in the literature and their inclusion within integrated STEM curriculum is often limited (Roehrig et al., 2021) (e.g., Roehrig et al., 2021)). Thus, it is critical that more explicit attention is given to mathematics and technology in the development of more robust and detailed models of integrated STEM education.

\section{The case of mathematics}

Despite a long history of integration between science and mathematics (e.g., Berlin \& White, 1995; Davison et al., 1995; Huntley, 1998), the integration of mathematics is particularly difficult within integrated STEM education (Walker, 2017; Zhang et al., 2015), and studies show only small impacts on students' mathematical knowledge (e.g., Becker \& Park, 2011; NAE and NRC, 2014; Nugent et al., 2015). For example, Huntley (1998) describes the interdisciplinary approach as having one discipline that is in the foreground with the second discipline in the background simply to provide context. However, most often in science (and more recently in integrated STEM lessons), mathematics is backgrounded as a tool for data measurement and analysis with few or no conceptual learning goals for mathematics (e.g., Baldinger et al., 2021; Ring et al., 2017; Roehrig et al., 2021; Walker, 2017). This treatment of mathematics is reinforced by the NGSS through the inclusion of mathematics and computational thinking as one of the eight science and engineering practices (NRC, 2012). This practice presents mathematics as a tool that is central to science and engineering (Hoda, Wilkerson, \& Fenwick, 2017) including "tasks ranging from constructing simulations, to making quantitative predictions, to statistically analyzing data, to recognizing, expressing, and applying quantitative relationships" (Aminger et al., 2021, p. 190).

While it is difficult to imagine teaching and learning science or engineering without engaging in mathematical practices, the mathematical connections are most often implicit and may not be transparent to students (Roehrig et al., 2021). Successful mathematics integration requires that the role of mathematics be made explicit, such as through putting mathematics in the foreground (Silk et al., 2010). For example, in a meta-analysis, Hurley (2001) found the greatest effect sizes for mathematics learning occurred when students learned science and mathematics content in sequence through a multidisciplinary approach, rather than interdisciplinary approaches. More recently, Baldinger et al. (2021) argued that science and mathematics learning opportunities need to be strategically positioned and highlighted across a unit. Indeed, as noted previously, conceptual learning of science and mathematics is improved through a multidisciplinary approach that allows mathematics and science concepts to be explicitly and purposefully foregrounded within a unit.

In a rare study of the implementation of mathematical and computational thinking in K-12 science classrooms, Aminger et al. (2021) found that teachers were able to improve students' understanding of scientific phenomena only when engaged in high cognitive demand mathematical tasks, such as mathematical modeling. Modeling uses mathematical equations to represent scientific phenomena and communicate scientific ideas (e.g., Bialek \& Botstein, 2004; Brush, 2015; Lazenby \& Becker, 2019). While students are expected to interpret the mathematical and scientific meaning represented by an equation (e.g., Bialek \& Botstein, 2004; Sevian \& Talanquer, 2014), studies at the postsecondary level show that students rely on algorithmic procedures without making connections between the mathematical equation and the scientific phenomenon (e.g., Bing \& Redish, 2009). Postsecondary researchers advocate for blended sensemaking, where students' scientific and mathematical knowledge is activated and used to develop understanding of scientific phenomena (Zhao \& Schuchardt, 2021). When instruction encourages engagement in mathematical modeling through blended sensemaking, students show improved quantitative problem solving (e.g., Becker, Rupp, \& Brandriet, 2017; Lazenby \& Becker, 2019; Schuchardt \& Schunn, 2016). 


\section{The case of technology}

Technology is rarely explicitly called out within definitions of integrated STEM education (e.g., Ellis et al., 2020; Herschbach, 2011). Implicit treatments of technology take two primary forms: the integration of educational technology and technology as the production and use of technology within engineering (Ellis et al., 2020; Kelley \& Knowles, 2016). Unquestionably, educational technology plays an increasingly large role in K-12 classrooms and, as is the case for all teachers, science teachers are involved in using digital technology tools to present content and allow students to complete their work, often through one-to-one technology initiatives. Standards guiding the use of technology in K-12 classrooms, such as the International Society for Technology in Education (ISTE) Standards for Educators, which define the technological skills educators need (ISTE, 2000), are content- and grade-level agnostic (Ellis et al., 2020). Most often, these digital technologies are used as replacements to traditional paper and text learning. For example, in science classrooms, digital notebooks have been used instead of paper notebooks (Constantine \& Jung, 2019). While this allows students to include multimedia such as photos and videos and work collaboratively through web-based tools, these uses of technology are not specific to STEM.

Given the focus on engineering within the NGSS, views of technology within integrated STEM education are often connected to how technology is portrayed within engineering curriculum. In a review of K-12 engineering curricula, technology was primarily represented as the product of engineering (NRC, 2009). This representation of technology within integrated STEM education is clearly stated within the NGSS where engineering is defined as "a systematic practice for solving problems, and technology as the result of that practice" (NRC, 2012, p. 103). Similarly, the Framework states that "technologies result when engineers apply their understanding of the natural world and of human behavior to design ways to satisfy human needs and wants" (NRC, 2012, p. 12). In essence, under this definition of the " $T$ " in STEM, STEM becomes SEM, resulting in technology being subsumed by engineering.

More productive in defining technology specific to integrated STEM education is the view of the "T" in STEM defined as the tools used by practitioners of science, mathematics, and engineering (Ellis et al., 2020; NAE and NRC, 2014). To support student engagement in the authentic practices of STEM professionals, students should have opportunities to use STEM-specific tools or technologies (e.g., Bell \& Bull, 2008; Ellis et al., 2020; McCrory, 2008). A common example in science classrooms is the use of digital probes to collect and analyze data (e.g., Hechter \& Vermette, 2014). More recently, with the addition of engineering into science classrooms, new technologies such as computer-assisted design (CAD) software and 3-D printers are being introduced (e.g., Wieselmann et al., 2019). Critical to integrated STEM education, however, is that these tools should not be limited to data collection devices; rather, they should encourage deeper student engagement with science content (Bull \& Bell, 2008). Moving beyond basic data practices, technology practices in STEM education can be elevated to incorporate simulation and modeling practices which have been shown to improve students' conceptual science understanding (Aminger et al., 2021).

\section{Summary of content integration}

Given the need for disciplinary knowledge to be activated and applied in integrated STEM lessons, there is a strong argument for a multidisciplinary approach where students have opportunities to both learn the content and connect that content to an authentic problem. Implicit connections are not enough; observations of instruction should yield clear and explicit discussion orchestrated by the teacher to facilitate students' understanding of the connections across the disciplines. The inter-relationships among the disciplines are complex and require teaching STEM content in deliberate and purposeful ways so that students understand how STEM content is conceptually linked. In the case of mathematics and technology, it is critical that these subjects are not limited to tools in the service of data collection and analysis. When appropriate, curriculum developers and teachers should engage students in higher cognitive demand practices and explicit sensemaking through mathematical and technology-assisted modeling. While the literature related to modeling in physics is more robust (e.g., Hestenes, 2010), modeling literature also exists in other scientific disciplines that can be used to guide higher quality mathematics integration (e.g., Lazenby \& Becker, 2019; Schuchardt \& Schunn, 2016; Zhao \& Schuchardt, 2021). Engagement in these data and mathematical practices, as practiced by STEM professionals, is a STEM-specific approach to technology integration.

\section{Integration through STEM practices and twenty- first century skills}

Also common across definitions of integrated STEM are references to specific disciplinary practices (e.g., inquiry, engineering design), as well as to shared practices and skills (e.g., critical thinking, creativity) (Moore et al., 2020). In addressing real-world problems and engineering design challenges, students should engage directly in authentic STEM practices (Characteristic 5) and twentyfirst century skills (Characteristic 6) to develop potential solutions (Fig. 1) (e.g., Kelley \& Knowles, 2016; Moore, Stohlmann, et al., 2014). The nature of the engineering 
design challenge is critical in promoting the desired learning outcomes and should be structured with multiple possible solution pathways. For example, if the task is too constrained, then the design space becomes limited, and students will not have the opportunity to develop important twenty-first century skills, such as critical thinking and creativity.

\section{STEM practices}

Engaging students in STEM practices is a common component of definitions of integrated STEM education (e.g., Kelley \& Knowles, 2016; Moore et al., 2020). These practices are "a representation of what practitioners do as they engage in their work and they are a necessary part of what students must do to learn a subject and understand the nature of the field" (Reynante et al., 2020, p.3). Engaging students in STEM practices is supported broadly by pragmatism, which emphasizes learning by doing (Asunda, 2014), and more specifically by social constructivist learning theories that underpin reforms in STEM education that advocate for students' active construction of knowledge as opposed to transmission of knowledge (e.g., Guzey, Moore, \& Harwell, 2016; Riskowski et al., 2009).

Central to knowledge construction and the work of STEM professionals are data practices (Duschl et al., 2007). Data practices include the creation, collection, manipulation, analysis, and visualization of data (Weintrop et al., 2016). Given that engineering design challenges afford multiple solution pathways without a single correct solution (Lachapelle \& Cunningham, 2014) and "data do not come with inherent structure that leads directly to an answer" (Weintrop et al., 2016, p. 135), it is important that students are actively engaged in data practices and using data to make decisions as they engage in the engineering design process. Within the Framework (NRC, 2012), this is called out as the practice of engaging in argument from evidence, which features the use of evidence and scientific and mathematical knowledge to develop explanations in science and justify design decisions in engineering.

Argumentation is a common practice within both science and engineering fields (Couso \& Simarro, 2020); however, while scientific argumentation is wellsupported within the research literature (e.g., Berland \& McNeill, 2010), the level to which K-12 students use both evidence and STEM content to justify design decisions is in its infancy (e.g., Mathis et al., 2018; Purzer et al., 2015; Valtorta \& Berland, 2015). Argumentation and decision-making require considering the advantages and disadvantages of possible design solutions in light of available evidence and any defined criteria and constraints (Wendell et al., 2017).
Siverling et al. (2017) argue that students' application of scientific and mathematical content is promoted through the explicit use of evidence-based reasoning within integrated STEM lessons. For example, the classroom activities may require students to justify their thinking about why an initial design solution should be pursued during the planning phase and additionally require students to use evidence and STEM content when evaluating a tested design solution and justifying it to the client (Mathis et al., 2016; Mathis et al., 2018). This formal evidence-based reasoning explicitly asks students to make claims about their designs and design decisions that are supported by both evidence (from iterative testing) and reasoning (using scientific and mathematical content) (Siverling et al., 2019). Students do not spontaneously use science and mathematics content to justify and explain their design choices; rather, students focus on cost and material limitations when engaging in engineering design tasks (e.g., English et al., 2013; Guzey \& Aranda, 2017). Thus, explicit inclusion of evidencebased reasoning in $\mathrm{K}-12$ integrated STEM lessons is necessary to scaffold students in connecting science and mathematics content to the engineering design challenge.

STEM content knowledge is not the only consideration in making design decisions. In evaluating a possible design solution, students are expected to prioritize "criteria and trade-offs that account for a range of constraints, including cost, safety, reliability, and aesthetics as well as possible social, cultural, and environmental impacts" (NGSS standard HS-ETS1-3). It is important that the social and cultural aspects of proposed solutions are not ignored, as we truly intend to develop a STEM literate citizenry and develop a future workforce who think more deeply about their work beyond the traditional technocratic focus (Gunckel \& Tolbert, 2018; Roehrig et al., 2020; Zeidler, 2016).

Students should have agency in design decisions as they engage in the engineering design process (e.g., Berland \& Steingut, 2016; Johnson et al., 2016; Saito et al., 2015). Engineering design challenges should be constructed with multiple solution pathways, allowing students to determine their own solution trajectories and opportunities to build knowledge as possible design solutions develop from students' questions, ideas, and explorations. Miller et al. (2018) argue that we must also position students as epistemic agents as opposed to receivers of STEM content, without which the call from the Framework (NRC, 2012) for students to engage in STEM practices will not be realized. Miller et al. (2018) define epistemic agency as "students being positioned with, perceiving, and acting on, opportunities to shape the knowledge building work in their classroom community" (p. 1058). Specifically, students should have 
opportunities to: (a) build on personal and cultural knowledge as a resource for learning, (b) build knowledge, (c) build a knowledge product that is personally useful, and (d) change structures that constrain and support action. When afforded epistemic agency, students can propose solutions to personally meaningful problems, rather than simply learning the canonical facts of the discipline (Schwarz et al., 2017) and mimicking the proscribed practices. Engaging students in engineering design challenges contextualizes learning around meaningful and authentic problems, providing a sense of agency as students can see the content learning goals as useful and relevant to developing solutions to the problem (e.g., Schwarz et al., 2017). Researchers argue that real-world problems should position students as not only knowledge builders, but also change agents in their community, further promoting epistemic agency and the development of STEM identity (Billington et al., 2013; Leammukda \& Roehrig, 2020; Miller et al., 2018).

\section{Twenty-first century skills}

In addition to specific STEM practices, integrated STEM instruction should support the development of twentyfirst century skills (e.g., Moore, Glancy, et al., 2014; Sias et al., 2017). Broadly, twenty-first century skills include knowledge construction, real-world problem solving, skilled communication, collaboration, use of information and communication technology for learning, creativity, and collaboration (Partnership for twenty-first Century Learning, 2016); these are the skills "necessary for a person to adapt and thrive in an ever-changing world" (Stehle \& Peters-Burton, 2019, p.2). A recent trend has been to include the arts, as proponents of STEAM education argue that the integration of the arts will enhance students' critical thinking and problem-solving skills and cultivate their creativity (Trevallion \& Trevallion, 2020). However, these arguments are already central to agreedupon goals of integrated STEM education (NAE and NRC, 2014; Moore, Glancy, et al., 2014), and creativity is pivotal within the STEM disciplines without the insertion of the arts. Integrated STEM education provides a rich environment for the development of critical thinking, collaboration, creativity, and communication (Stehle \& Peters-Burton, 2019).

The ill-defined nature of real-world problems and engineering design challenges requires that students engage in critical thinking, drawing on their STEM content knowledge and lived experiences to propose possible design solutions. Engaging in the engineering design process inherently incorporates creativity and critical thinking as there is no single correct solution, thus promoting the potential of transformative and innovative design solutions (Stretch \& Roehrig, 2021; Petroski, 2016; Simpson et al., 2018). As students iteratively test and improve their design solutions, they will experience design failure. As previously noted, failure should be expected if innovation is to occur, and the ability to learn from failure can lead to stronger designs and innovation through the application of creativity and critical thinking (Henry et al., 2021; Simpson et al., 2018).

Given the highly interdisciplinary and integrative nature of engineering, students should also be provided opportunities to work together in teams to enhance their collaboration skills (Riel et al., 2012; Rinke et al., 2016; Thibaut et al., 2018), which are necessary to develop negotiated design solutions that synthesize across differing understandings of the same problem space (Wendell et al., 2017). Indeed, in the K-12 classroom, small group activities account for approximately half of instructional time in science classrooms with the expectation that small groups co-construct knowledge of STEM content and design solutions to real-world problems (Wieselmann et al., 2020; Wendell et al., 2017). Sharunova et al. (2020) used Bloom's taxonomy (Anderson \& Krathwohl, 2005) to define a continuum of cognitive engagement that groups engage in during small group engineering design activities. Integrated STEM learning environments involve "new levels of communication, shared vision, collective intelligence, and direct coherent action by students" (Asunda, 2014, p. 8). Further, researchers call for integrated STEM activities wherein students are expected to collectively apply what they have learned to develop possible design solutions and improve these designs through iterative analysis and evaluation (Asunda et al., 2015; Dolog et al., 2016; Sharunova et al., 2020).

\section{Promoting STEM careers}

The final characteristic, promoting STEM careers (Characteristic 7), is the least common feature of integrated STEM within the literature. As such, it stands somewhat separate from the other characteristics of the integrated STEM framework but undergirds the policy motivation for including integrated STEM education in K-12 classrooms. With the goal of promoting future participation in STEM careers in mind, integrated STEM education should expose students to details about STEM careers (Jahn \& Myers, 2014; Luo et al., 2021). This should include both allowing students to engage in the authentic work of STEM professionals (Kitchen et al., 2018; Ryu et al., 2018) and critically promoting student development of STEM identities. A growing body of research has shown that STEM interest, attitude, and identity serve as predictors of sustained pursuit in the STEM disciplines rather than academic performance in STEM coursework (Avraamidou, 2020; Rodriguez et al., 2017; Tai et al., 2006). Furthermore, identity research has shown that students who show interest and enjoyment in STEM do not necessarily see themselves pursuing a 
future STEM career (Carlone et al., 2011); this is especially true for students from historically underrepresented groups of people who are less likely to show interest in and identify with the STEM domains (Rodriguez et al., 2017). Further, STEM interests and career aspirations are largely developed by eighth grade (Tai et al., 2006), suggesting a need to introduce students to STEM careers early in their education. In addition to introducing students to STEM careers, research shows that a focus on connections to personal experience and knowledge can help shape students' identity within STEM (Ryu et al., 2018; Carlone et al., 2014; Sias et al., 2017).

Although supporting students in developing solutions to real-world problems through engaging in STEM practices and twenty-first century skills may also help to develop positive STEM identities and interest in STEM, these activities do not require any explicit connection to STEM careers. Research exploring the development of students' understanding of engineering is limited and debate remains about whether implicit modeling of STEM professions by engaging students in hands-on STEM activities leads to durable and robust understandings about the work of engineers and other STEM professionals (e.g., Svihla et al., 2017). However, explicit discussion of STEM professions can help students to understand specific career opportunities and align these professions with their interests (Kitchen et al., 2018; Ryu et al., 2018).

\section{Implications and use of the framework}

Each of the seven critical characteristics of integrated STEM education (Table 1) has important implications for teachers in their planning and implementation of integrated STEM if integrated STEM in K-12 classrooms is going to be successful in promoting STEM literacy and increasing diversity in the STEM fields. Careful consideration is critical in selecting the context for an integrated STEM lesson, as research shows differences in motivation to engage in STEM for students of color and women who are under-represented in STEM as compared to White males (e.g., Billington et al., 2013; Diekman et al., 2010; Leammukda \& Roehrig, 2020). While some science topics lend themselves to simple engineering design activities, such as designing a mousetrap car to travel as far as possible, these activities are not contextualized in a real-world problem. In contrast, students could be asked to design habitats to protect equatorial penguins impacted by climate change, a problem that requires knowledge and application of the scientific concepts of heat transfer (Sheerer \& Schnittka, 2012). This engineering design challenge is contextualized by a realworld problem created through human impact on the environment and could easily be adapted to include considerations of human-caused environmental issues and local policies and traditions in developing design solutions. By contextualizing an engineering design challenge in a real-world problem, we ask students not only to understand the technical criteria and constraints of a problem but also to consider the problem within the context of a potentially difficult moral and ethical dilemma. Teachers should seize such opportunities to guide students in sense-making, understanding the authenticity of the context, and approach these problems with a critical perspective. Attention to selecting realworld problems and related engineering design challenges that promote positive STEM identities for students that are under-represented in STEM not only addresses reported workforce needs but brings new perspectives and approaches to how STEM content and practices are applied in the real-world.

Unfortunately, even with a real-world context, engineering design tasks can degenerate into tinkering and iterative improvement of designs through random trial and error (McComas \& Burgin, 2020; Moore, Glancy, et al., 2014; Roehrig et al., 2021) if these integrated STEM lessons are poorly planned. As well as providing a motivating context designed to promote positive STEM identities, the real-world problem and engineering design challenge must provide a context for learning specified STEM content. This could involve the reactivation of prior knowledge or the explicit teaching of STEM content within a unit of instruction. We suggest that a pedagogical approach closer to multidisciplinary integration might better afford students' recognition of the STEM content inherent within an integrated STEM unit. In other words, quality integrated STEM units (e.g., Bhattacharya et al., 2015; Karahan et al., 2014; Moore, Guzey, et al., 2014; Moore et al., 2015) should include lessons designed to explicitly teach relevant STEM content. Given that students rarely make these connections spontaneously (Tran \& Nathan, 2010), it is critical that teachers use specific pedagogical approaches, such as evidence-based reasoning (Mathis et al., 2016; Mathis et al., 2018), to help make these connections explicit. Strong teacher facilitation and questioning is needed to help students recognize the connections across the disciplines and use these connections to develop stronger design solutions through iterative and reflective processes.

Our integrated STEM framework helps to not only provide more specific guidance to educators, but also support for integrated STEM research. Despite the push for integrated STEM in K-12 classrooms, the development of observation protocols that assess STEMintegrated teaching has been slow. Until valid protocols are developed, STEM education researchers continue to rely on existing instruments that predate current STEM education initiatives, such as the Reformed Teaching 
Observation Protocol (Sawada et al., 2002). The lack of a detailed integrated STEM framework thus far has prevented the field from systematically collecting data in classrooms to understand the nature and quality of integrated STEM instruction; this delays research related to the impact on student outcomes, including academic achievement and affect. This framework provides detailed guidance on teacher practices one would expect to observe within an integrated STEM lesson. With this framework, the groundwork is now set for researchers to explore the impact of specific aspects of integrated STEM or the overall quality of integrated STEM instruction on student outcomes as this framework could guide the development of observational protocols for integrated STEM which are currently lacking in the field (e.g., Dare et al., 2021).

\section{Conclusions}

Our framework addresses a critical need in the field to move beyond simple definitions of integrated STEM to detailed descriptions that operationalize central constructs such as the nature of integration itself. Based on intentions of STEM policy documents and the extant literature, we proposed an integrated STEM framework that includes seven key characteristics of integrated STEM: (a) focus on real-world problems, (b) centrality of engineering, (c) context integration, (d) content integration, (e) STEM practices, (f) twenty-first century skills, and (g) informing students about STEM careers. While these key characteristics include commonly agreed upon components of integrated STEM (e.g., Johnson et al., 2016; Kelly \& Knowles, 2016; Moore, Stohlmann, et al., 2014), our framework conceptualizes each of the key characteristics in detail, operationalizing integrated STEM for educators, curriculum developers, and researchers. This is critical as statements such as "an effort to combine some or all of the four disciplines of science, technology, engineering, and mathematics into one class, unit, or lesson that is based on connections between the subjects and real-world problems" (Moore, Stohlmann, et al., 2014, p. 38) do not provide enough information about critical issues such as how to integrate any subset of the STEM disciplines or what real-world problems would be appropriate to drive learning in STEM for all students.

Most importantly, our framework directly attends to issues of diversity and equity as current definitions and implementation of integrated STEM are content-focused and consider only the technical aspects of engaging in solving real-world problems and/or engineering design challenges. Our framework specifically addresses issues raised by critics of integrated STEM (e.g., Gunckel \& Tolbert, 2018; Roehrig et al., 2020; Zeidler, 2016) to give full consideration to the socio-historical-political context in which the engineering design challenge resides and use this knowledge in making design decisions. The framework also attends to the development of STEM identities for all students through understanding how the nature of the real-world problem and/or engineering design challenge can constrain or afford interest and engagement in STEM for girls and students of color (e.g., Billington et al., 2013; Diekman et al., 2010; Leammukda \& Roehrig, 2020). Also important to promoting positive STEM identities for all students is elevating students' lived experiences and cultural knowledge as valid forms of knowledge to be drawn on as they engage in developing solutions to real-world problems.

\section{Abbreviations}

NAE: National Academy of Engineering; NAS: National Academy of Science; NGSS: Next Generation Science Standards; NRC: National Research Council; PCAST: President's Council of Advisors on Science and Technology; SSI: Socio-scientific Issues; STEM: Science-Technology-EngineeringMathematics

\section{Acknowledgements}

This research was made possible by the National Science Foundation grants 1854801, 1812794, and 1813342. The findings, conclusions, and opinions herein represent the views of the authors and do not necessarily represent the view of personnel affiliated with the National Science Foundation.

\section{Authors' contributions}

GR wrote the manuscript based on substantive discussions with $E D$, JE, and ERW. ED, JE, and ERW provided significant feedback on the manuscript. All authors read and approved the final manuscript.

\section{Funding}

This research was made possible by the National Science Foundation grants 1854801, 1812794, and 1813342. The findings, conclusions, and opinions herein represent the views of the authors and do not necessarily represent the view of personnel affiliated with the National Science Foundation.

\section{Availability of data and materials}

Data sharing is not applicable to this article as no datasets were generated or analyzed during the current study.

\section{Declaration}

\section{Competing interests}

The authors declare that they have no competing interests.

\section{Author details}

${ }^{1}$ Department of Curriculum and Instruction, University of Minnesota, Minneapolis, USA. ${ }^{2}$ Department of Teaching and Learning, Florida International University, Miami, USA. ${ }^{3}$ National Center for STEM Elementary Education, St. Catherine University, St Paul, USA.

Received: 7 June 2021 Accepted: 26 November 2021

Published online: 13 December 2021

\footnotetext{
References

Adams Becker, S., Freeman, A., Giesinger Hall, C., Cummins, M., \& Yuhnke, B. (2016). NMC/COSN horizon report: 2016 K-12 edition. The New Media Consortium.

Aminger, W., Hough, S., Roberts, S. A., Meier, V., Spina, A. D., Pajela, H., ... Bianchini, J. A. (2021). Preservice secondary science teachers' implementation of an NGSS practice: Using mathematics and computational thinking. Journal of Science Teacher Education, 32(2), 188-209. https://doi.org/10.1080/104 $6560 \times .2020 .1805200$.
} 
Anderson, L. W., \& Krathwohl, D. (2005). A taxonomy for learning, teaching, and assessing: A revision of bloom's taxonomy of educational objectives. Educational Horizons, 83(3), 154-159.

Arık, M., \& Topçu, M. S. (2020). Implementation of engineering design process in the K-12 science classrooms: Trends and issues. Research in Science Education. Published online. https://doi.org/10.1007/s11165-019-09912-x.

Asunda, P. A. (2014). A conceptual framework for STEM integration into the curriculum through career and technical education. Journal of STEM Teacher Education, 49(1), 3-16. https://doi.org/10.30707/JSTE49.1Asunda.

Asunda, P. A., \& Mativo, J. (2017). Integrated STEM: A new primer for teaching technology education. Technology \& Engineering Teacher, 76(5), 14-19.

Australian Curriculum, Assessment, and Reporting Authority (2016). ACARA STEM Connections Project Report. Retrieved from https://www.australiancurriculum. edu.au/media/3220/stem-connections-report.pdf

Avraamidou, L. (2020). "I am a young immigrant woman doing physics and on top of that I am Muslim": Identities, intersections, and negotiations. Journal of Research in Science Teaching, 57(3), 311-341. https://doi.org/10.1002/tea.21 593.

Baldinger, E. D., Staats, S., Covington-Clarkson, L. M., Gullickson, E., Norman, F., \& Akoto, B. (2021). In Returning voice to the silent M: A review of conceptions of mathematics in integrated STEM education, J. Anderson, \& Y. Li (Eds.), Integrated approaches to STEM education: An international perspective, (pp. 67-90). Dordrecht: Springer.

Becker, K., \& Park, K. (2011). Effects of integrative approaches among science, technology, engineering, and mathematics (STEM) subjects on students' learning: A preliminary meta-analysis. Journal of STEM Education, 12(5/6), $23-$ 37.

Becker, N. M., Rupp, C. A., \& Brandriet, A. (2017). Engaging students in analyzing and interpreting data to construct mathematical models: An analysis of students' reasoning in a method of initial rates task. Chemistry Education Research and Practice, 18(4), 798-810. https://doi.org/10.1039/C6RP00205F.

Bell, R. L., \& Bull, G. (2008). Technology's greatest value. In R. L. Bell, J. GessNewsome, \& J. Luft Technology in the secondary science classroom (91-96). NSTA Press.

Berland, L. K., \& McNeill, K. L. (2010). A learning progression for scientific argumentation: Understanding student work and designing supportive instructional contexts. Science Education, 94(5), 765-793. https://doi.org/10.1 002/sce.20402.

Berland, L. K., \& Steingut, R. (2016). Explaining variation in student efforts towards using math and science knowledge in engineering contexts. International Journal of Science Education, 38(18), 2742-2761. https://doi.org/10.1080/ 09500693.2016.1260179.

Berlin, D. F., \& White, A. L. (1995). In Connecting school science and mathematics, P. A. House, \& A. F. Coxford (Eds.), Connecting mathematics across the curriculum. 1995 National Council of teachers of mathematics yearbook, (pp. 22-33). Reston: National Council of Teachers of Mathematics.

Bhattacharya, D., Guzey, S. S., Millar, C., \& Moore, T. (2015). Artificial floating islands: A curriculum unit for integrated STEM. Science Scope, 38(9), 63-69. https://doi.org/10.2505/4/ss15_038_09_63.

Bialek, W., \& Botstein, D. (2004). Introductory science and mathematics education for 21st-century biologists. Science, 303(5659), 788-790. https://doi.org/10.112 6/science.1095480.

Billington, B., Britsch, B., Karl, R., Carter, S., Freese, J., \& Regalla, L. (2013). SciGirls Seven - How to engage girls in STEM. Retrieved from: http://www. scigirlsconnect.org/scigirls

Bing, T. J., \& Redish, E. F. (2009). Analyzing problem solving using math in physics: Epistemological framing via warrants. Physical Review Special Topics - Physics Education Research, 5(2), 020108. https://doi.org/10.1103/PhysRevSTPER.5.0201 08.

Blackley, S., Sheffield, R., Maynard, N., Koul, R., \& Walker, R. (2017). Makerspace and reflective practice: Advancing pre-service teachers in STEM education. Australian Journal of Teacher Education, 42(3), 22-37. https://doi.org/1 0.14221 /ajte.2017v42n3.2

Bronson, P., \& Merryman, A. (2011). The creativity crisis, (pp. 1-7). Newsweek. https://doi.org/10.1037/e574802013-336.

Brush, G. (2015). Mathematics as an instigator of scientific revolutions. Science \& Education, 24(5-6), 495-513. https://doi.org/10.1007/s11191-015-9762-X.

Burrows, A., Lockwood, M., Borowczak, M., Janak, E., \& Barber, B. (2018). Integrated STEM: Focus on informal education and community collaboration through engineering. Education Sciences, 8(4). https://doi. org/10.3390/educsci8010004.
Bybee, R. W. (2013). A case for STEM education. Arlington: National Science Teachers' Association Press.

Capobianco, B. M., \& Rupp, M. (2014). STEM teachers' planned and enacted attempts at implementing engineering design-based instruction. School Science Mathematics, 114(6), 258-270. https://doi.org/10.1111/ssm.12078.

Carlone, H. B., Haun-Frank, J., \& Webb, A. (2011). Assessing equity beyond knowledge- and skills-based outcomes: A comparative ethnography of two fourth-grade reform-based science classrooms. Journal of Research in Science Teaching, 48(5), 459-485. https://doi.org/10.1002/tea.20413.

Carlone, H. B., Scott, C. M., \& Lowder, C. (2014). Becoming (less) scientific: A longitudinal study of students' identity work from elementary to middle school science. Journal of Research in Science Teaching, 51(7), 836-869. https://doi.org/10.1002/tea.21150.

Carter, V., Beachner, M., \& Daugherty, M. K. (2015). Family and consumer sciences and STEM integration. Journal of Family \& Consumer Sciences, 107(1), 55-58.

Cavlazoglu, B., \& Stuessy, C. L. (2017). Identifying and verifying earthquake engineering concepts to create a knowledge base in STEM education: A modified Delphi study. International Journal of Education in Mathematics, Science and Technology, 5(1), 40-52. https://doi.org/10.18404/ijemst.60674.

Chandan, D., Magana, A. J., \& Vieira, C. (2019). Investigating the affordances of a CAD enabled learning environment for promoting integrated STEM learning. Computers \& Education, 129, 122-142. https://doi.org/10.1016/j.compedu.201 8.10.014.

Charyton, C. (2015). Creative engineering design: The meaning of creativity and innovation in engineering. In C. Charyton (Ed.), Creativity and innovation among science and art: A discussion of the two cultures (135-152). SpringerVerlag Publishing, https://doi.org/10.1007/978-1-4471-6624-5_7.

Constantine, A., \& Jung, K. (2019). Using digital science notebooks to support elementary student learning: Lessons and perspectives from a fifth-grade science classroom. Contemporary Issues in Technology and Teacher Education, 19(3), 373-412

Couso, D., \& Simarro, C. (2020). Unveiling the challenge of STEM Transdisciplinarity. In Handbook of research on STEM education, Johnson, C. C., Mohr-Schroeder, M. J., Moore, T. J., \& English, L. D. , 17-28. New York: Routledge, https://doi.org/10.4324/9780429021381-3.

Cunningham, C. M., \& Carlsen, W. S. (2014). Teaching engineering practices. Journal of Science Teacher Education, 25(2), 197-210. https://doi.org/10.1007/ s10972-014-9380-5.

Dare, E. A., Ellis, J. A., \& Roehrig, G. H. (2018). Understanding science teachers' implementations of integrated STEM curricular units through a phenomenological multiple case study. International Journal of STEM Education, 5(4), 4. https://doi.org/10.1186/s40594-018-0101-z.

Dare, E. A., Hiwatig, B., Keratithamkul, K., Ellis, J. A., Roehrig, G. H., Ring-Whalen, E. A., ... Crotty, E. A. (2021). In Improving integrated STEM education: The design and development of a K-12 STEM observation protocol (STEM-OP) (RTP) (Ed.), Proceedings of the 2021 ASEE Annual Conference \& Exposition https://peer.asee.org/improving-integrated-stem-education-the-design-anddevelopment-of-a-k-12-stem-observation-protocol-stem-op-rtp.pdf.

Davison, D. M., Miller, K. W., \& Metheny, D. L. (1995). What does integration of science and mathematics really mean. School Science and Mathematics, 95(5), 226-230. https://doi.org/10.1111/j.1949-8594.1995.tb15771.x.

Diekman, A. B., Brown, E. R., Johnston, A. M., \& Clark, E. K. (2010). Seeking congruity between goals and roles: A new look at why women opt out of science, technology, engineering, and mathematics careers. Psychological Science, 21(8), 1051-1057. https://doi.org/10.1177/0956797610377342.

Djonko-Moore, C., Leonard, J., Holifield, Q., Bailey, E., \& Almughyirah, S. (2018). Using culturally relevant experiential education to enhance urban children's knowledge and engagement in science. The Journal of Experimental Education, 41(2), 137-153.

Dolog, P., Thomsen, L. L., \& Thomsen, B. (2016). Assessing problem-based learning in a software engineering curriculum using Bloom's taxonomy and the IEEE software engineering body of knowledge. ACM Transactions on Computing Education, 16(3), 1-41. https://doi.org/10.1145/2845091.

Duschl, R. A., Schweingruber, H. A., \& Shouse, A. W. (2007). Taking science to school: Learning and teaching science in grades K-8. Washington, DC: National Academies Press.

Dym, C. (1999). Learning engineering: Design, languages, and experiences. Journal of Engineering Education, 88(2), 145-148. https://doi.org/10.1002/j.21 68-9830.1999.tb00425.x.

Ellis, J., Wieselmann, J., Sivaraj, R., Roehrig, G., Dare, E., \& Ring-Whalen, E. (2020). Toward a productive definition of technology in science and STEM 
education. Contemporary issues in technology and teacher education, 20(3), 1 https://citejournal.org/volume-20/issue-3-20/science/toward-a-productivedefinition-of-technology-in-science-and-stem-education/.

English, L. D. (2016). STEM education K-12: Perspectives on integration. International Journal of STEM Education, 3(1), 1-8. https://doi.org/10.1186/s4 0594-016-0036-1.

English, L. D., Hudson, P., \& Dawes, L. (2013). Engineering-based problem solving in the middle school: Design and construction with simple machines construction with simple machines. Journal of Pre-College Engineering Education Research, 3, 43-55.

European Commission (2015). Science education for responsible citizenship. Brussels: European Union.

Fan, S. C., \& Yu, K. C. (2017). How an integrative STEM curriculum can benefit students in engineering design practices. International Journal of Technology and Design Education, 27(1), 107-129. https://doi.org/10.1007/s10798-015-932 $8-x$.

Freeman, B., Marginson, S., \& Tytler, R. (2014). The age of STEM: Educational policy and practice across the world in science, technology, engineering and mathematics. New York: Routledge. https://doi.org/10.4324/9781315767512.

Friesen, M. R., \& Herrmann, R. (2018). In Indigenous knowledge, perspectives, and design principles in the engineering curriculum (Ed.), Proceeding of the 2018 Canadian engineering education association conference, paper 010. Columbia: University of British. https://doi.org/10.24908/pceea.v0i0.12964.

Gunckel, K. L., \& Tolbert, S. (2018). The imperative to move toward a dimension of care in engineering education. Journal of Research in Science Teaching, 55(7), 938-961. https://doi.org/10.1002/tea.21458.

Guzey, S. S., \& Aranda, M. (2017). Student participation in engineering practices and discourse: An exploratory case study. Journal of Engineering Education, 106(4), 585-606. https://doi.org/10.1002/jee.20176.

Guzey, S. S., Harwell, M., Moreno, M., Peralta, Y., \& Moore, T. J. (2017). The impact of design-based STEM integration curricula on student achievement in engineering, science, and mathematics. Journal of Science Education and Technology, 26(2), 207-222. https://doi.org/10.1007/s10956-016-9673-x.

Guzey, S. S., Moore, T., \& Morse, G. (2016). Student interest in engineering designbased science. School Science and Mathematics, 116(8), 411-419. https://doi. org/10.1111/ssm.12198.

Guzey, S. S., Moore, T. J., \& Harwell, M. (2016). Building up STEM: An analysis of teacher-developed engineering design-based STEM integration curricular materials. Journal of Pre-College Engineering Education Research, 6(1), 11-29. https://doi.org/10.7771/2157-9288.1129.

Hechter, R., \& Vermette, L. A. (2014). Tech-savvy science education? Understanding teacher pedagogical practices for integrating technology in K-12 classrooms. Journal of Computers in Mathematics and Science Teaching, 33(1), 27-47

Henry, M. A., Shorter, S., Charkoudian, L. K., Heemstra, J. M., Le, B., \& Corwin, L. A. (2021). Quantifying fear of failure in STEM: Modifying and evaluating the performance failure appraisal inventory (PFAI) for use with STEM undergraduates. International Journal of STEM Education, 8(43). https://doi. org/10.1186/s40594-021-00300-4

Herschbach, D. R. (2011). The STEM initiative: Constraints and challenges. Journal of STEM Teacher Education, 48(1), 96-112. https://doi.org/10.30707/JSTE48.1 Herschbach.

Hestenes D. (2010) Modeling theory for math and science education. In: Lesh R., Galbraith P., Haines C., Hurford A. (Eds) Modeling Students' mathematical modeling competencies. Springer, Boston, https://doi.org/10.1007/978-1-441 9-0561-1_3.

Hoda Wilkerson, M., \& Fenwick, M. (2017). Using mathematics and computational thinking. In C. V. Schwarz, C. Passmore, \& B. J. Reiser, Helping students make sense of the world: Using next generation science and engineering practices (181-204). National Science Teachers Association.

Hoeg, D. G., \& Bencze, J. L. (2017). Values underpinning STEM education in the USA: An analysis of the next generation science standards. Science Education, 101(2), 278-301. https://doi.org/10.1002/sce.21260.

Hong, O. (2017). STEAM education in Korea: Current policies and future directions. Policy Trajectories and Initiatives in STEM Education, 8(2), 92-102.

Householder, D. L., \& Hailey, C. E. (Eds.). (2012). Incorporating engineering design challenges into STEM courses. Retrieved from http://ncete.org/flash/pdfs/ NCETECaucusReport.pdf.

Huntley, M. A. (1998). Design and implementation of a framework for defining integrated mathematics and science education. School Science and
Mathematics, 98(6), 320-327. https://doi.org/10.1111/j.1949-8594.1998.tb1742 7.x.

Hurley, M. M. (2001). Reviewing integrated science and mathematics: The search for evidence and definitions from new perspectives. School Science and Mathematics, 101(5), 259-268. https://doi.org/10.1111/j.1949-8594.2001.tb1802 8.x.

International Society for Technology in Education. (2020). Be bold with us. Retrieved from https://www.iste.org/about/about-iste

Jackson, C., Mohr-Schroeder, M. J., Bush, S. B., Maiorca, C., Roberts, T., Yost, C., \& Fowler, A. (2021). Equity-oriented conceptual framework for K-12 STEM literacy. International Journal of STEM Education, 8(38). https://doi.org/10.11 86/s40594-021-00294-z.

Jahn, J. L. S., \& Myers, K. K. (2014). Vocational anticipatory socialization of adolescents: Messages, sources, and frameworks that influence interest in STEM careers. Journal of Applied Communication Research, 42(1), 85-106. https://doi.org/10.1080/00909882.2013.874568.

Johnson, C. C., Peters-Burton, E. E., \& Moore, T. J. (2016). STEM road map: A framework for integrated STEM education. New York: Routledge.

Kahn (2015). Another " $M$ " for STEM? Moral considerations for advancing STEM literacy. K-12. STEM Education, 1(4), 149-156.

Karahan, E., Guzey, S., \& Moore, T. (2014). Saving pelicans: A STEM integration unit. Science Scope, 38(3), 28-34. https://doi.org/10.2505/4/ss14_038_03_28.

Kelley, T. R., \& Knowles, J. G. (2016). A conceptual framework for integrated STEM education. International Journal of STEM Education, 3(1), 1-11. https://doi. org/10.1186/s40594-016-0046-z.

Kilada, G., Thomsen, V., Seniuk Cicek, J., Mante, A. A., \& Herrmann, R. (2021). The impact of indigenous knowledges and perspectives in engineering education: One student's story. Proceedings of 2021 Canadian engineering education association conference, paper 115.

Kim, K. (2011). The creativity crisis: The decrease in creative thinking scores on the Torrance tests of creative thinking. Creativity Research Journal, 23(4), 285295. https://doi.org/10.1080/10400419.2011.627805.

Kitchen, J. A., Sonnert, G., \& Sadler, P. M. (2018). The impact of college-and university-run high school summer programs on students' end of high school STEM career aspirations. Science Education, 102(3), 529-547. https:// doi.org/10.1002/sce.21332.

Kloser, M., Wilsey, M., Twohy, K. E., Immonen, A. D., \& Navotas, A. C. (2018). "we do STEM": Unsettled conceptions of STEM education in middle school S.T.E. M. classrooms. Schoo/ Science \& Mathematics, 118(8), 335-347. https://doi. org/10.1111/ssm.12304

Lachapelle, C., \& Cunningham, C. (2014). Engineering in elementary schools. In S. Purzer, J. Strobel, \& M. Cardella, Engineering in pre-college settings: Synthesizing research, policy, and practices (61-88). West Lafayette: Purdue University Press, https://doi.org/10.2307/j.ctt6wq7bh.8.

Lazenby, K., \& Becker, N. M. (2019). A modeling perspective on supporting students' reasoning with mathematics in chemistry. In M. H. Towns, K. Bain, \& J.-M. G. Rodriguez, It's just math: Research on students' understanding of chemistry and mathematics (1316, 9-24).

Leammukda, F. D., \& Roehrig, G. H. (January, 2020). Community-based conceptual framework for STEM integration. San Antonio: Paper presented at the annual meeting of the Association for Science Teacher Education.

Lederman, N. G., \& Niess, M. L. (1997). Integrated, interdisciplinary, or thematic instruction? Is this a question or is it questionable semantics. School Science and Mathematics, 97(2), 57-58. https://doi.org/10.1111/j.1949-8594.1997.tb1 7342.X.

Lin, Y.-S. (2011). Fostering creativity through education--a conceptual framework of creative pedagogy. Creative Education, 2(3), 149-155. https://doi.org/10.423 6/ce.2011.23021

Luo, T., So, W. W. M., Wan, Z. H., \& Li, W. C. (2021). STEM stereotypes predict students' STEM career interest via self-efficacy and outcome expectations. International Journal of STEM Education, 8(36). https://doi.org/10.1186/s40594021-00295-y

Martin, M., \& Schinzinger, R. (1989). Ethics in engineering. New York: McGraw-Hill.

Mathis, C. A., Siverling, E. A., Glancy, A., Guzey, S. S., \& Moore, T. J. (2016). In Students' use of evidence-based reasoning in K-12 engineering: A case study (Fundamental) (Ed.), Proceedings of ASEE Annual Conference and Exposition, Conference Proceedings. New Orleans: ASEE.

Mathis, C. A., Siverling, E. A., Moore, T. J., Douglas, K. A., \& Guzey, S. S. (2018). Supporting engineering design ideas with science and mathematics: A case study of middle school life science students. International Journal of 
Education in Mathematics, Science and Technology, 6, 424-442. https://doi. org/10.18404/ijemst.440343.

McComas, W. F., \& Burgin, S. R. (2020). A critique of "STEM" education revolutionin-the-making, passing fad, or instructional imperative. Science \& Education, 29(4), 805-829. https://doi.org/10.1007/s11191-020-00138-2.

McCrory, R. (2008). In Science, technology, and teaching: The topic-specific challenges of TPCK in science (Ed.), AACTE Committee on Innovation and Technology, Handbook of technological pedagogical content knowledge (TPCK) for educators, (pp. 193-206). Routledge.

McLure, F. I., Koul, R. B., \& Fraser, B. J. (2021). Gender differences among students undertaking iSTEM projects in multidisciplinary vs uni-disciplinary STEM classrooms in government vs non-govermnment schools: Classroom emotional climate and attitudes. Learning Environments Research. https://doi. org/10.1007/s10984-021-09392-9.

Mehalik, M., Doppelt, Y., \& Schunn, C. D. (2008). Middle school science through design-based learning versus scripted inquiry: Better overall science concept learning and equity gap reduction. Journal of Engineering Education, 97(1), 71-85. https://doi.org/10.1002/j.2168-9830.2008.tb00955.x.

Miller, E., Manz, E., Russ, R., Stroupe, D., \& Berland, L. (2018). Addressing the epistemic elephant in the room: Epistemic agency and the next generation science standards. Journal of Research in Science Teaching, 55(7), 1053-1075. https://doi.org/10.1002/tea.21459.

Monson, D., \& Besser, D. (2015). Smashing milk cartons: Third-grade students solve a real-world problem using the engineering design process, collaborative group work, and integrated STEM education. Science and Children, 52(9), 38-43. https://doi.org/10.2505/4/sc15_052_09_38.

Moore, T., Guzey, S. S., \& Brown, A. (2014). Greenhouse design to increase habitable land: An engineering unit. Science Scope, 37(7), 51-57.

Moore, T. J., Doerr, H. M., Glancy, A. W., \& Ntow, F. D. (2015). Preserving pelicans with models that make sense. Mathematics Teaching in the Middle School 20(6), 358-364. https://doi.org/10.5951/mathteacmiddscho.20.6.0358.

Moore, T. J., Glancy, A. W., Tank, K. M., Kersten, J. A., \& Smith, K. A. (2014). A framework for quality K-12 engineering education: Research and development. Journal of Pre-College Engineering Education Research, 4(1), 113. https://doi.org/10.7771/2157-9288.1069.

Moore, T.J., Johnston, A.C., \& Glancy, A.W. (2020). STEM integration: A synthesis of conceptual frameworks and definitions. In Johnson, C.C., Mohr-Schroeder, M. J., Moore, T.J., \& English, L.D. (Eds.), Handbook of research on STEM education. (3-16) Routledge, https://doi.org/10.4324/9780429021381-2.

Moore, T. J., \& Smith, K. A. (2014). Advancing the state of the art of STEM integration. Journal of STEM Education, 15(1), 5-10.

Moore, T. J., Stohlmann, M. S., Wang, H.-H., Tank, K. M., Glancy, A., \& Roehrig, G. H. (2014). Implementation and integration of engineering in K-12 STEM education. In J. Strobel, S. Purzer, \& M. Cardella (Eds.), Engineering in precollege settings: Research into practice. Rotterdam: Sense Publishers.

Nathan, M. J., Srisurichan, R., Walkington, C., Wolfgram, M., Williams, C., \& Alibalia, M. W. (2013). Building cohesion across representations: A mechanism for STEM integration. Journal of Engineering Education, 102(1), 77-116. https://doi. org/10.1002/jee.20000.

National Academy of Engineering and National Research Council (2014). STEM integration in K-12 education: Status, prospects, and an agenda for research. Washington: National Academies Press.

National Academy of Sciences (2004). The engineer of 2020: Visions of engineering in the new century. Washington: National Academies Press.

National Academy of Sciences, National Academy of Engineering, and Institute of Medicine of the National Academies (2007). Rising above the gathering storm: Energizing and employing America for a brighter economic future. Washington: National Academies Press.

National Association of Manufacturing and Deloitte Report (2018). 2018 Deloitte and The Manufacturing Institute skills gap and future of work study. Retrieved from https://www.themanufacturinginstitute.org/wp-content/uploa ds/2020/03/MI-Deloitte-skills-gap-Future-of-Workforce-study-2018.pdf

National Research Council (2009). Engineering in K-12 education: Understanding the status and improving the prospects. The National Academies Press.

National Research Council (2012). A framework for K-12 science education: Practices, crosscutting concepts, and core ideas. Washington: National Academies Press.

NGSS Lead States (2013). Next generation science standards: For states, by states. Washington: National Academies Press.

Nugent, G., Barker, B., Welch, G., Grandgenett, N., Wu, C., \& Nelson, C. (2015). A model of factors contributing to STEM learning and career orientation.
International Journal of Science Education, 37(7), 1067-1088. https://doi.org/1 0.1080/09500693.2015.1017863.

Owens, D. C. \& Sadler, T. D., (2020). Socio-scientific issues as contexts for the development of STEM literacy. In Johnson, C.C., Mohr-Schroeder, M.J., Moore, T.J., \& English, L.D. (Eds.), Handbook of research on STEM education. (210222) Routledge, https://doi.org/10.4324/9780429021381-20.

Partnership for 21st Century Learning. (2016). Framework for 21st century learning. Retrieved from www.p21.org/about-us/p21-framework.

Petroski, H. (2016). To engineer is human: The role of failure in successful design. Defense AR Journal, 23(1), 106-109.

President's Council of Advisors on Science and Technology (2011). Report to the president: Prepare and inspire: K-12 education in science, technology, engineering, and mathematics (STEM) for America's future. Washington: Executive Office of the President.

Purzer, S., Goldstein, M. H., Adams, R. S., Xie, C., \& Nourian, S. (2015). An exploratory study of informed engineering design behaviors associated with scientific explanations. International Journal of STEM Education, 2(9), 1-12. https://doi.org/10.1186/s40594-015-0019-7.

Rennie, L., Wallace, J., \& Venville, G. (2012). Exploring curriculum integration: Why integrate? In L. Rennie, G. Venville, \& J. Wallace (Eds.), Integrating science, technology, engineering, and mathematics (1-11). New York: Routledge, https://doi.org/10.4324/9780203803899.

Reynante, B. M., Selbach-Allen, M. E., \& Pimentel, D. R. (2020). Exploring the promises and perils of integrated STEM, through disciplinary practices and epistemologies. Science \& Education, 29(4), 785-803. https://doi.org/10.1007/ s11191-020-00121-X.

Riel, A., Draghici, A., Draghici, G., Grajewski, D., \& Messnarz, R. (2012). Process and product innovation needs integrated engineering collaboration skills. Journal of Software: Evolution and Process, 24(5), 551-560.

Ring, E. A., Dare, E. A., Crotty, E. A., \& Roehrig, G. H. (2017). The Evolution of Teacher Conceptions of STEM Education Throughout an Intensive Professional Development Experience. Journal of Science Teacher Education, 28(5), 444-467. https://doi.org/10.1080/1046560X.2017.1356671.

Rinke, C. R., Gladstone-Brown, W., Kinlaw, C. R., \& Cappiello, J. (2016). Characterizing STEM teacher education: Affordances and constraints of explicit STEM preparation for elementary teachers. School Science and Mathematics, 116(6), 300-309. https://doi.org/10.1111/ssm.12185.

Riskowski, J. L., Todd, C. D., Wee, B., Dark, M., \& Harbor, J. (2009). Exploring the effectiveness of an interdisciplinary water resources engineering module in an eighth-grade science course. International Journal of Engineering Education, 25(1), 181-195.

Rodriguez, S., Cunningham, K., \& Jordan, A. (2017). STEM identity development for Latinas: The role of self- and outside recognition. Journal of Hispanic Higher Education, 18(3), 254-272. https://doi.org/10.1177/1538192717739958.

Roehrig, G. H., Dare, E. A., Ring-Whalen, E. A., \& Wieselmann, J. R. (2021), Understanding coherence and integration in integrated STEM curriculum. International Journal of STEM Education, 8(2). https://doi.org/10.1186/s40594020-00259-8

Roehrig, G.H., Keratithamkul, K., \& Hiwatig, B. (2020). Intersections of integrated STEM and socio-scientific issues. In W. Powell (Ed.) Socioscientific issuesbased instruction for scientific literacy development. IGI Global.

Ryu, M., Mentzer, N., \& Knobloch, N. (2018). Preservice teachers' experiences of STEM integration: Challenges and implications for integrated STEM teacher preparation. International journal of technology and design education, 29(3), 120. https://doi.org/10.1007/s10798-018-9440-9.

Saito, T., Gunji, Y., \& Kumano, Y. (2015). The problem about technology in STEM education: Some findings from action research on the professional development \& integrated STEM lessons in informal fields. K-12 STEM Education, 1(2), 85-100. https://doi.org/10.14456/k12stemed.2015.16.

Sawada, D., Piburn, M. D., Judson, E., Turley, J., Falconer, K., Benford, R., \& Bloom, I. (2002). Measuring reform practices in science and mathematics classrooms: The reformed teaching observation protocol. School Science and Mathematics, 102(6), 245-253. https://doi.org/10.1111/j.1949-8594.2002.tb1 7883.x.

Schuchardt, A. M., \& Schunn, C. D. (2016). Modeling scientific processes with mathematics equations enhances student qualitative conceptual understanding and quantitative problem solving. Science Education, 100(2), 290-320. https://doi.org/10.1002/sce.21198.

Sevian, H., \& Talanquer, V. (2014). Rethinking chemistry: A learning progression on chemical thinking. Chemistry Education Research and Practice, 15(1), 10-23. https://doi.org/10.1039/C3RP00111C. 
Sgro, C.M., Bobowski, T., \& Oliveira, A. W. (2020). Current praxis and conceptualization of STEM education: A call for greater clarity in integrated curriculum development. In V. Akerson and G. Buck (Eds.) Contemporary trends and issues in science education: Critical questions in STEM education (185-210) Dordrecht: Springer, https://doi.org/10.1007/978-3-030-57646-2_11.

Sharunova, A., Wang, Y., Kowalski, M., \& Qureshi, A. J. (2020). Applying Bloom's taxonomy in transdisciplinary engineering design education. International Journal of Technology and Design Education. https://doi.org/10.1007/s10798020-09621-X.

Sheffield, R., Koul, R., Blackley, S., \& Maynard, N. (2017). Makerspace in STEM for girls: A physical space to develop 21st century skills. Educational Media International, 54(2), 148-164. https://doi.org/10.1080/09523987.2017.1362812.

Shuman, L., Besterfield-Sacre, M., \& McGourty, J. (2005). The ABET professional skills-can they be taught? Can they be assessed. Journal of Engineering Education, 94(1), 41-55. https://doi.org/10.1002/j.2168-9830.2005.tb00828.x.

Sias, C. M., Nadelson, L. S., Juth, S. M., \& Seifert, A. L. (2017). The best laid plans: Educational innovation in elementary teacher generated integrated STEM lesson plans. The Journal of Educational Research, 110(3), 227-238. https://doi. org/10.1080/00220671.2016.1253539.

Silk, E. M., Higashi, R., Shoop, R., \& Schunn, C. D. (2010). Designing technology activities that teach mathematics. The Technology Teacher, 69(4), 21-27.

Simpson, E., Bradley, D., \& O'Keeffe, J. (2018). Failure is an option: An innovative engineering curriculum. International Journal of Building Pathology and Adaptation, 36(3), 268-282. https://doi.org/10.1108/JJBPA-10-2017-0046.

Siverling, E. A., Suazo-Flores, A., Mathis, C. A., \& Moore, T. J. (2019). Students' use of STEM content in design justifications during engineering design-based STEM integration. School Science and Mathematics, 119(8), 457-474. https:// doi.org/10.1111/ssm.12373.

Siverling, E. A., Suazo-Flores, E., Mathis, C. A., Moore, T. J., Guzey, S. S., \& Whipple, K. S. (2017). Middle school students' engineering discussions: What initiates evidence-based reasoning? (Fundamental). ASEE Annual Conference and Exposition, Conference Proceedings.

Stehle, S. M., \& Peters-Burton, E. E. (2019). Developing student 21 st century skills in selected exemplary inclusive STEM high schools. International Journal of STEM Education, 6(1), 6. https://doi.org/10.1186/s40594-019-0192-1.

Stretch, E. J., \& Roehrig, G. H. (2021). Framing failure: Leveraging uncertainty to launch creativity in STEM education. International Journal of Learning and Teaching, 7(2), 123-133. https://doi.org/10.18178/ijlt.7.2.123-133.

Svihla, V., Marshall, J., Winter, A., \& Liu, Y. (2017). In ASEE Annual Conference and Exposition, Conference Proceedings (Ed.), Progress toward lofty goals: A Metasynthesis of the state of research on K-12 engineering education (fundamental).

Tai, R. T., Liu, C. Q., Maltese, A. V., \& Fan, X. (2006). Planning early for careers in science. Science, 312(5777), 1143-1144. https://doi.org/10.1126/science.112 8690.

Takeuchi, M. A., Sengupta, P., Shanahan, M.-C., Adams, J. D., \& Hachem, M. (2020). Transdisciplinarity in STEM education: A critical review. Studies in Science Education, 56(2), 213-253. https://doi.org/10.1080/03057267.2020.1755802.

Tan, E., \& Calabrese Barton, A. (2018). Towards critical justice: Exploring intersectionality in community-based STEM-rich making with youth from non-dominant communities. Equity \& Excellence in Education, 51(1), 48-61. https://doi.org/10.1080/10665684.2018.1439786.

Tank, K. M., Pleasants, J. B., \& Olson, J. K. (2019). Elementary teachers' attempts at integrating science and engineering over the course of a semester. Baltimore: Paper presented at the NARST international meeting.

Thibaut, L., Knipprath, H., Dehaene, W., \& Depaepe, F. (2018). How school context and personal factors relate to teachers' attitudes toward teaching integrated STEM. International Journal of Technology \& Design Education, 28(3), 631-651. https://doi.org/10.1007/s10798-017-9416-1.

Tran, N. A., \& Nathan, M. J. (2010). Pre-college engineering studies: An investigation of the relationship between pre-college engineering studies and student achievement in science and mathematics. Journal of Engineering Education, 99(2), 143-157. https://doi.org/10.1002/j.2168-9830.2010.tb01051.x.

Trevallion, D., \& Trevallion, I. (2020). STEM: Design, implement and evaluate. International Journal of Innovation, Creativity and Change, 14(8), 1-19.

U.S. Bureau of Labor Statistics (2020). Employment in STEM Occupations. Retrieved from https://www.bls.gov/emp/tables/stem-employment.htm

Vakil, S., \& Ayers, R. (2019). The racial politics of STEM education in the USA: Interrogations and explorations. Race Ethnicity and Education, 22(4), 449-458. https://doi.org/10.1080/13613324.2019.1592831.

Valtorta, C. G., \& Berland, L. K. (2015). Math, science, and engineering integration in a high school engineering course: A qualitative study. Journal of Pre-
College Engineering Education Research, 5(1), 15-29. https://doi.org/10.7771/21 57-9288.1087.

Vasquez, J., Sneider, C., \& Comer, M. (2013). STEM lesson essentials, grades 3-8, integrating science, technology, engineering, and mathematics. Portsmouth: Heinemann.

Walker III, W. S. (2017). Integrated STEm or integrated STEM. School Science and Mathematics, 117(6), 225-227. https://doi.org/10.1111/ssm.12234.

Walker III, W. S., Moore, T. J., Guzey, S. S., \& Sorge, B. H. (2018). Frameworks to develop integrated STEM curricula. K-12 STEM Education, 4(2), 331-339. https://doi.org/10.14456/k12stemed.2018.5.

Wang, H.-H., \& Knobloch, N. A. (2018). Levels of STEM integration through agriculture, food, and natural resources. Journal of Agricultural Education, 59(3), 258-277. https://doi.org/10.5032/jae.2018.03258.

Wang, H.-H., Moore, T. J., Roehrig, G. H., \& Park, M. S. (2011). STEM integration: The impact of professional development on teacher perception and practice. Journal of Pre-College Engineering Education Research, 1(2), 1-13.

Weintrop, D., Beheshti, E., Horn, M., Orton, K., Jona, K., Trouille, L., \& Wilensky, U. (2016). Defining computational thinking for mathematics and science classrooms. Journal of Science Education and Technology, 25(1), 127-147. https://doi.org/10.1007/s10956-015-9581-5.

Wendell, K. B., Wright, C. G., \& Paugh, P. (2017). Reflective decision-making in elementary students' engineering design. Journal of Engineering Education, 106(3), 356-397. https://doi.org/10.1002/jee.20173.

Wieselmann, J., Sonquist, B., Halupczok, S., \& Peters, M. (2019). Teacher-tested tips for integrating 3-D printing technologies into the science classroom. Science Scope, 43(2), 26-33. https://doi.org/10.2505/4/ss19_043_02_26.

Wieselmann, J. R., Dare, E. A., Ring-Whalen, E. A., \& Roehrig, G. H. (2020). "I just do what the boys tell me": Exploring small group student interactions in an integrated STEM unit. Journal of Research in Science Teaching, 57(1), 112-144. https://doi.org/10.1002/tea.21587.

World Economic Forum (2016). Five Million Jobs by 2020: the Real Challenge of the Fourth Industrial Revolution. Retrieved from https://www.weforum.org/ press/2016/01/five-million-jobs-by-2020-the-real-challenge-of-the-fourthindustrial-revolution/

Zeidler, D. L. (2016). STEM education: A deficit framework for the twenty first century? A sociocultural socio-scientific response. Cultural Studies of Science Education, 11(1), 11-26. https://doi.org/10.1007/s11422-014-9578-z.

Zeidler, D. L., Herman, B. C., Clough, M. P., Olson, J. K., Kahn, S., \& Newton, M. (2016). Humanitas emptor: Reconsidering recent trends and policy in science teacher education. Journal of Science Teacher Education, 27(5), 465-476. https://doi.org/10.1007/s10972-016-9481-4.

Zhang, D., Orrill, C., \& Campbell, T. (2015). Using the mixture Rasch model to explore knowledge resources students invoke in mathematics and science assessments. School Science and Mathematics, 115(7), 356-365. https://doi. org/10.1111/ssm.12135.

Zhao, F., \& Schuchardt, A. (2021). Development of the Sci-math Sensemaking framework: Categorizing sensemaking of mathematical equations in science. International Journal of STEM Education, 8(10). https://doi.org/10.1186/s40594020-00264-x

\section{Publisher's Note}

Springer Nature remains neutral with regard to jurisdictional claims in published maps and institutional affiliations.

\section{Submit your manuscript to a SpringerOpen ${ }^{\circ}$ journal and benefit from:}

- Convenient online submission

- Rigorous peer review

- Open access: articles freely available online

- High visibility within the field

- Retaining the copyright to your article

Submit your next manuscript at $\boldsymbol{\nabla}$ springeropen.com 